\title{
Colorectal Cancer pMX TNM Finding v6
}

National Cancer Institute

\section{Source}

National Cancer Institute. Colorectal Cancer pMX TNM Finding v6. NCI Thesaurus. Code C60854.

Colorectal cancer in which distant metastases cannot be assessed. (from AJCC 6th Ed.) 